Journal of Cultural Studies, vol. 32, núm. 3, 2018, pp. 460-476.

\title{
Talks and disputes of racism in Colombia after multiculturalism.
}

\author{
Restrepo, Eduardo.
}

Cita:

Restrepo, Eduardo (2018). Talks and disputes of racism in Colombia after multiculturalism. Journal of Cultural Studies, 32 (3), 460-476.

Dirección estable: https://www.aacademica.org/eduardo.restrepo/58 ARK: https://n2t.net/ark:/13683/ph6y/3ha

https://creativecommons.org/licenses/by-nc-nd/4.0/deed.es.

Acta Académica es un proyecto académico sin fines de lucro enmarcado en la iniciativa de acceso abierto. Acta Académica fue creado para facilitar a investigadores de todo el mundo el compartir su producción académica. Para crear un perfil gratuitamente o acceder a otros trabajos visite: https://www.aacademica.org. 


\title{
Talks and disputes of racism in Colombia after multiculturalism*
}

\author{
Eduardo Restrepo \\ Department of Cultural Studies, Pontificia Universidad Javeriana, Bogotá, Columbia
}

\begin{abstract}
This article examines the terms that shape the notion of ethnic group for black communities. This notion allows one to understand the singularity of Colombia's turn to multiculturalism in the 1990s, and how it has impacted the political and theoretical imaginations of cultural otherness. I will argue that this shift to multiculturalism has not meant the disappearance of the talks and disputes of racism and the beginning of a kind of 'post-racial' social formation. On the contrary, old and new forms of talk and disputes of racism could be traced after this shift to multiculturalism, not only in relation to the dense legislation for the recognition of black communities as ethnic groups, but also in regard to other realms such as social media, activist struggles and academic paradigms.
\end{abstract}

KEYWORDS Racism; Afro-descendants; multiculturalism; Colombia

\section{Introduction}

I believe, with Gramsci, that we must attend 'violently' to things as they are, without illusions or false hopes, if we want to transcend the present. (Hall 1988, p. 14).

Colombia is the country with the third highest Afro-descendant population in the Americas, and the first in Hispanic America. In official data, Afro-Colombians constitute more than 10 percent of the population, although some organizations consider them to be at least a quarter of Colombia's inhabitants. In some regions of the country, such as the Colombian Pacific, Afro-Colombians comprise 90-95 percent of the population. Other areas of the country also present a clear presence of black people, such as the insular and continental Caribbean, as well as the inter-Andean valleys. Most Afro-Colombians live in cities like Cali, Cartagena, Medellin and Bogota.

Although some people could argue that there is no racism in the country, many more are those who consider the opposite. ${ }^{1}$ Despite the different opinions, the practices of racialization and racial discrimination 
in Colombia have been documented extensively and in detail (see Wade 1993, Urrea et al. 2014). Some public debates in the media and social networks about situations of virulent racism make it possible to verify not only the permanence of old forms of racism, but also the emergence of new ones.

With the shift to multiculturalism in the 1990s, which involved the recognition by the state of the black communities as an ethnic group with specific territorial and cultural rights, substantial transformations were generated in the theoretical and political imaginaries about the Afro-Colombian populations. Nevertheless, their inclusion in a regime of otherness that equated them with indigenous peoples did not mean the ending of the old forms of racism or the advent of a 'post-racial' social formation. On the contrary, 15 years after the official turn to multiculturalism, speeches and disputes of racism seem to be ever more recurrent and visible.

Talks and disputes of racism is a concept inspired by the notion of 'talk of crime' suggested by the Brazilian anthropologist Teresa de Caldeira (2001). With talks and disputes of racism, I mean the multiple narratives woven around experiences of racism, public disputes as well as the political and academic analyses of racism. The talks and disputes of racism are not simply the expression at the level of the language of a reality that exists independently and that precedes them; rather, they have a significant effect on informing racism and its experiences. Instead of being a stable set of narratives, talks and disputes of racism are profoundly contextual.

As Hall (1985) reminds us, experience is not exterior to the categories and representations that constitute us. Experiences of racism are not ahistorical nor are they transparent expressions of social structure. An attitude or practice can be experienced as racist or not since lived experiences depend largely on the principles of intelligibility and the common senses that constitute us. I do not want to argue that racism is simply a subjective experience, rather I affirm that it being experienced or not as such is a constituent part of racism, and that these experiences are transformed historically and contextually. If we do not want to fall into the old problems of false consciousness or into the dead ends of a notion of 'race in itself' and 'race for itself', we must take seriously that even if it is not only discourse, experience is discursively constituted.

My argument here is an invitation to pay a closer political and theoretical attention to historization and radical contextualism, both so relevant to the cultural studies project. In Hall's words, understanding the specificity and historical difference that establishes difference in a determined social formation would enable us to position ourselves in a more convenient spot for political intervention and transformation. 


\section{The shift to multiculturalism}

In Colombia, the shift to multiculturalism finds within the Political Constitution of 1991 one of its most visible referents, since this document introduces as one of its principles the ethnic and cultural diversity of the nation. This Constitution represents a substantial transformation in some aspects from the Constitution of 1886. The traditional Colombian political elite had imagined the foundation of citizenship and of the nation in a project based on the Eurocentric ideology. From this perspective, indigenous and some black people who lived in Colombia were expressions of 'previous stages' in the civilizing process and therefore constituted a sort of still-not-citizens until they were redeemed from their condition of savagery (Arias 2005).

The form of multiculturalism adopted in Colombia does not consider multiple nationalities or peoples that constitute the Colombian state, as it has happened in Bolivia; rather, it simply recognizes that the Colombian nation (still one nation and not multiple ones) is multi-ethnic and multicultural. Hence, it is the concept of 'ethnic group' (operating legally and politically from the idea of 'ethnic minority') that articulates what has been called the 'differentiated approach' to some state policies and measures (Lopera and Dover 2013).

With the Constitution of 1991, indigenous communities were the explicit subjects of territorial, economic, educational and political-administrative dispositions, while black communities found only in a transitory article (Transitory Article 55) the possibilities to materialize their specific rights. This asymmetry is the result of multiple factors which include, according to Wade (1993), different social and conceptual places occupied by 'Indians' and 'Blacks' in the 'structures of alterity' configured since the colonial period. In this case, indigenous people were part of the political and theoretical paradigm of what was defined as an ethnic group, while black communities in most scenarios were not considered a part of such representations until the early 1990s. However, with the regulation derived from Transitory Article 55, such as 1993's Law 70 and the subsequent trail of rulings from the Constitutional Court, a dense legal framework has outlined the terms, scope and limitations of the shift to multiculturalism for black communities in the country.

It is necessary to examine the terms that shape the notion of ethnic group to understand the singularity regarding Colombia's turn to multiculturalism in the 1990s, and how it has affected the transformations that have happened in the country since then, alongside their ranges and limitations. In a preliminary stage of this turn, the definition of ethnic group operated in a very particular semantic field: the one concerning traditional communities, mainly rural, with cultural features that place them as 'authentically Others', a kind of alien outside the 'West' and 'modernity'. In legal discourse as well as in the 
academic and political ones, the idea that indigenous communities (or rather, certain indigenous communities) define the paradigm of what is an ethnic group has prevailed. The existence of markers of difference, such as those cultural and linguistic, expressed in certain territorialized communal and traditional life forms, are often refer to define a given population as an ethnic group.

Now, embodied cultural difference is not enough to become an ethnic group in Colombia. Inhabitants of the Caribbean coast, for example, have huge linguistic and cultural differences with the rest of the country. Nonetheless, they are not usually thought of as an ethnic group, but as a regional difference. Another remarkable example is the one of the paisas. This word is used nation-wide to describe or refer to individuals from the region more or less comprised by the department of Antioquia. Paisas are easily identifiable by their particular accent and cultural singularities, but mostly by a deep sense of belonging and an attitude of hyper-valuation of whatever is theirs. However, this difference is not usually discussed in terms of ethnicity, but it is framed within the discourse of regional difference and sometimes even as racial difference.

What makes it possible to be addressed and positioned as an ethnic group is a certain configuration of cultural difference, such as the logic of ancestrality, communality, authenticity, territoriality, collective ownership and environmental harmony located in certain rural places. In a way, they constitute a set of representations that presents them as the antipodes of modernity, development, capitalism and the 'West'. Using a concept suggested by Rita Laura Segato (2007), these are 'the Others of the nation', those who, in addition, and thanks to the shift to multiculturalism, become the 'nation otherwise'.

In this initial stage of the turn to multiculturalism, not all black people (whether they recognized themselves as such or not) could fit in the ethnic group position. The first to fit and be recognized above all others were certain rural black communities from the Colombian Pacific region, those who had been represented as having traditional production practices, collective territoriality exercises, traditional forms of cultural difference and authority. A large part of Afro-Colombians or black people who lived in big cities like Cali, Bogota, Cartagena and Medellin could only appear as an ethnic group in a very restricted manner during this phase of the turn to multiculturalism. The same happened with rural populations or people of medium and small urban conglomerates of the valleys and continental Caribbean. Experiences and aspirations of one another largely escaped the terms in which policies and struggles derived from this early phase were weaving.

Another aspect of great relevance to this matter is that in several places of the rural Pacific, the notion of black communities was configured, not without quarrelling, to include populations that were not locally marked as black 
people. This is the case of lower Atrato river, where black communities included non-black people what they called 'people of good faith', i.e. the chilapos and even some paisas (Ruíz 2008), or also the case of the nariñense Pacific coast where some culimochos (a white population) bow to the laws of black communities established in 1993's Law 70 (Hoffmann 2007).

The fact that not all black people were considered as ethnic groups, or that people who were not locally considered as blacks could be included within the spectrum of black communities (both as legal and political subjects) brings out one of the essential elements of the turn to multiculturalism in its initial state in Colombia: this was not plain and simple racial multiculturalism, but an ethnic-culturalist one. I am not trying to state here that the ethnicculturalist sphere is in absolute externality to the principles of intelligibility of racial thought; nonetheless, it isn't simply applied as an euphemism for racial distinction towards all ethnic subjects who could be racially ascribed as black (neither to all indigenous populations).

The political imaginary was deeply impacted by this shift to multiculturalism in the 1990s. The idea that black people are an ethnic group with a traditional production system, given practices, a particular territory, a traditional culture, that develop harmonious relationships with nature and possess a group identity was the result of an arduous and contradictory process of imagination and negotiation in academic and political areas at different levels (national, regional and local). Once this ethnicization of black communities was articulated in the early 1990s, it was established through the decade as the dominant representation of black communities, in such a way that it established the most relevant constituent criteria in the black political movement and state policies. Dissents, criticisms and alternatives were precisely built against or in relationship with this hegemonic representation. In this context, discourses and organizational strategies revolving around racial articulations of blackness mostly bowed to the hegemony of a political and legal subject of black communities as 'ethnic group'.

This distinctive aspect of the initial stage of the shift to multiculturalism is key to understand certain state policies and government strategies, as well as the terms and forms of deployment of the movements and the struggles carried out by organized sectors of 'black communities'. It is precisely this aspect that is transformed in a second phase of the shift to multiculturalism, in which certain limits of ethnic-culturalist multiculturalism overflow (without breaking entirely with it) to a stage where a diasporic-culturalist racialism is developed around the notions of Afro, Afro-descendant and Afro-Colombian, its legal and political subject.

The Afro, Afro-descendant and Afro-Colombian categories suggest the establishment of a political subject in terms of shared historical experiences (middle passage, slavery, racism and marginalization), as well as a positioning for citizen participation from a politics of difference which no longer holds an 
exclusively ethnic-culturalist approach. The scenarios for the political subject of Afro-descent are not principally those of the coastal rural Pacific, rather it refers to big cities (Cali, Bogota, Medellin) and, increasingly, transnational networks with meetings in Brazil, the United States and Europe or virtually on the Internet. Their central topics are neither territory nor culture, but political visibility, anti-racist struggle and socio-economic equity. So, today, on the ground of certain policies and struggles, individuals or communities can be ascribed and/or position themselves as an ethnic group, although they are not necessarily able or willing to subscribe to the representations of rural, sea-side or riverine commonalities with traditional production practices, harmonious relationships with nature and a collective territory as those assumed to the Pacific region.

This Afro-descendant political subject should not be simply considered as the overcoming of ethnicization (of black communities) since both concepts coexist, sometimes in certain tension. Nor should they be thought of as an absolute novelty, since some of its foundational premises had been advanced by black struggles and organizations like Cimarron even before the shift to multiculturalism in the 1990s.

In addition to this mark on Colombia's turn to multiculturalism articulated from the ethnic group (in both of the phases we have differentiated), another important feature has been their 'perverse confluence' (Dagnino 1998) with neo-liberalism. As indicated by Hale (2006), neo-liberal multiculturalism is characterized by a kind of legal and political recognition of cultural difference that does not problematize substantially or contradict the processes of structural adjustment and the positioning of neo-liberal models.

In Colombia, both the shift to multiculturalism and the consolidation of neo-liberal policies converge in the Constitution of 1991. The government of Cesar Gaviria, where this Constitution was sanctioned, is remembered as a time of radicalization of neo-liberal policies and structural adjustment with the privatization of state enterprises, measures which were implemented under the vocabulary of state 'modernization' and 'economic liberalization'. Since the 1990s, the discourse of progress/development and the economic model in Colombia has deepened neo-liberalism. Today, although with some additions of social programmes with obvious patronage aspirations, discourses of development that support and encourage extractivism are the foundations of a neo-liberal model that has no desire to limit and will not mind sacrificing any (social) contribution of the legislation associated with the multicultural shift if it seriously opposes or limits their interests.

These neo-liberal assumptions are so naturalized among political elites in Colombia that one of the arguments of biggest public boast in the Dialogues in Havana with the FARC was the non-negotiability of the country's economic model. Hence, the progress in terms of rights that may have occurred in recent decades (mainly as a result of Law 70 of 1993 and the rulings of the 
Constitutional Court) within the context of the shift to multiculturalism for Afro-descendants is limited in practice by the concrete expressions of the neo-liberal model and particularly by its articulations with extractive and developmental projects, as well as its coexistence with powerful illegal and criminal structures.

Another peculiarity of the shift to multiculturalism in Colombia comes from the paradoxical situation of having a particular fetish with legislation, on the one hand, and a limitation of the rule of law in much of the country's geography, on the other. It is common in Colombia that the issuance of a new decree or law incites passionate debates, where all efforts and hopes to regulate or transform reality are deposited in the legislation. This fetish with the law is not only the elites, but it is experienced in other ways by subalternized sectors including black populations and their organizational expressions. In this case, the law has a performative effect, a sort of aura that brings to life what is stated there (Lemaitre 2009, Rosas 2013).

Now, the shift to multiculturalism cannot be simply seen as a matter imposed from above by a political elite. It has largely been the result of organizational processes endorsed by black sectors of the population in alliance with progressive sectors of the church, academics and NGOs (Restrepo 2013). Within the shift to multiculturalism, they managed to articulate an unusual organizational movement around their recognition as an ethnic group that promoted a massive agrarian reform mainly in the Colombian Pacific region (more than five million acres were designated as collective territories for black communities). For the beginning of the millennium, within the framework of globalization of this organizational movement, the political subject that was focused on coastal rural communities in the Pacific region has expanded to one that, under the images of the diaspora and some experiences of marginalization and racial discrimination, seeks to appeal to Afrodescendants in urban centres and other regions of the country.

\section{Talks and disputes of racism and the shift to multiculturalism}

In the context of the shift to multiculturalism, the legal framework and the series of rights that have been sanctioned for the black communities in particular and Afro-descendants in general have enabled a series of reactions that articulate new talks and disputes of racism. Among these reactions, one can identify those who argue that supposedly this legislation is racist. Thus, since the enactment of Law 70 of 1993, there are publications in the local and national press that reject it with this argument. An example is the article by José Mosquera, entitled 'The hidden face of the Law of Negritude'. Questioning the relevance of the collective titling of the lands of black communities, Mosquera writes: 'Given that there are privileges and exclusions for an ethnic group regarding land tenure in one region over the others, this fact 
preserves racial discrimination in a region with high percentages of miscegenation among blacks, "whites" and Indians' (1995). This racism is also manifested, according to Mosquera, in the law on education:

Racism is clearer in the educational field when it is said that 'curricula must originate from the culture of the black communities' in mestizo places like the Pacific [...] Then closes the discussion of discrimination when it indicates in one of its articles: 'The state must guarantee the right of black communities to create their own institutions of education and communications', that is to say, to design unique and exclusive educational policies for blacks, and thus to separate them from the education that the State is providing.

This is just one example, among many, of reactions that denounce the legislation resulting from the shift to multiculturalism for being 'racist'. The texts from a legislation that was sanctioned in order to recognize rights to subalternized social sectors, in the name of overcoming historical and structural inequalities, paradoxically appears in the eyes of some as texts that promote 'racism'. Many of those who see these texts as racist do so on the grounds that such legislation prevents black communities from actually accessing the benefits of development and modernity. Some do not even hesitate to compare this legislation linked to the shift to multiculturalism with the Apartheid regime in South Africa (Valencia 1998, p. 181).

Thus, talks and disputes over racism have been linked to the process of ethnicization of black communities. Turning to multiculturalism has triggered reactions from various sectors (some of them from black intellectuals) that refuse to imagine black communities as an ethnic group in the terms defined by legislation and embodied in the speeches and organizational strategies that appeal to this legal and political subject named black communities.

Sectors with business interests and the local political elites, especially in the Pacific area, have also reacted to this legislation arguing that by guaranteeing territorial rights to black communities, this text instigates racism and produces alleged segregation effects. Nevertheless, what has bothered these commercial and elite groups the most are the limitations this legislation poses to their usual practices of exploiting natural resources or appropriating the lands that belong to these communities. In the Colombian Pacific region, for instance, sawmill owners, miners and Naidí Palm businessmen accused the ethnic-territorial organizations of black communities of advancing a 'racist agenda' that disregarded other populations and opposed the benefits of development (Escobar 2008).

Even though one may completely disagree with the criteria cited by those opposed to the particular way in which the shift to multiculturalism informs black communities, my goal for this article is to highlight how talks of racism not only do not disappear with the turn to multiculturalism, but they 
operate as a principle of intelligibility to account for and articulate some disputes that seek to undermine the scope of rights achieved by black communities as an ethnic group.

These talks and disputes over racism may be registered even in judicial questioning to the existent terminology of the legislation used by the state to recognize rights to black communities. Thus, for example, we can find a claim presented to the Constitutional Court claiming the unconstitutionality of the expression 'black communities', a term largely used in the legislative framework that made the shift to multiculturalism possible. In Sentence C253/13 of 25 April 2013, the Constitutional Court responds to Harold Javier Palacios, who demands 'that the expression "black communities" be declared unconstitutional because it has a negative and racist connotation that disavows the rights of the Afro-Colombian population' (Judgment C-253/13, p. 27) The plaintiff pointed out that

it is not correct to use the language that remained as a legacy of this fateful episode [that of slavery], it is by no means correct to worship this fact using the same qualifier as the slave owners did, as it happens with the use of the word black against people from Africa, without knowing the negative consequences that this word had in that historical moment and has now. (cited in Judgment C-253/13, p. 3)

The Constitutional Court's response to the complaint is supported by three central arguments: (1) the multilocality of language and its historical transformations question the mandatory articulation of a signifier and a meaning, (2) the contextual reading of the term that makes sense in the aforementioned legislation is not one of contempt and discrimination and 3) the increasing amount of people who claim themselves as and identify with the term black, even from organizational processes.

Rather than considering the Constitutional Court's response as adequate or not, my purpose is to call attention to the fact that what the disagreements over the 'racist' content of the legislation actually show is that the talk and disputes of racism were not ended by the shift to multiculturalism, rather they have been strengthened in some aspects by it.

\section{The media and social networks: visualizing talks and disputes of racism}

Talks and disputes of racism are not solely centred on debates regarding the legislation, but they have also revolved around some situations that have become relevant in the media and on social networks. Thus, for example, in mid-September 2015, in the busy streets of the historical centre of Bogota, two policemen pulled Carlos Angulo from the hurried crowd going to their jobs with the following words: 'A search, Negro'. Outraged by the contemptuous manner in which he was treated and by the discrimination of being 
arrested in the midst of the flow of passers-by, Carlos Angulo is recorded by another passer-by while he loudly rebuked the policemen: 'Why don't you search them? Because they are white, they are citizens, they are of this city and they do not represent a hazard'. The video of two and a half minutes, uploaded on social networks, became viral. Soon, the video was discussed by the press and newscasts, which caused a cascade of reactions and comments. Multiple reactions both for and against were registered in social media and in the discussion forums of the portals where the news was published, everyone from academics, journalists or activists had something to say about it; simultaneously this humble carpenter from Tumaco was congratulated and criticized.

Carlos Angulo's video portrays how racism is experimented in everyday life and spoken about in the media and social networks. Even though most daily experiences of racism do not get such coverage, it seems that lately these issues are more frequent and visible. Carlos Angulo's case is not the only, not even the most scandalous one. In recent years, both the media and social networks have recorded a series of events that appear explicitly as expressions of racism and have led to the most dissimilar reactions. Situations in which people are prevented from accessing public establishments in Cartagena, Bogotá or Cali because of their skin colour and physical features have sparked debates about the persistence of practices of racial discrimination that establish abject corporal markings. Some of these allegations have had legal implications, although this is not the most common.

One can also find in the media and social networks discussions about the relevance or not of affirmative action deployed in university admissions for Afro-descendants. The fact that some of the people who benefited from these actions do not seem to comply with the dominant imaginaries of being 'really black' has led the more conservative sectors to question the few initiatives of affirmative action that exist in some universities in the country. Some writers have even publicly questioned the relevance of this type of action in a country such as Colombia, unleashing a torrent of reactions against or in favour of their arguments.

The election of two representatives in the last congressional elections by a special constituency for black communities has also been a debate aired in the media and social networks. This time, the complaint came from some prominent Afro-Colombian activists and organizations, who criticized their credentials as representatives of the black communities since they are not actually 'black', both because of their phenotypic traits and their political trajectories that drift away from the interests and agendas of black communities.

In recent years, there have also been debates about racist representations in the media. Among the most notorious one is the scandal sparked by the cover image of the Spanish magazine Hola, which displayed white women from the elite of Cali, photographed in a scenario of ostentation and privilege, 
while two black women appeared in the background as their 'servants'. Also, one of the most traditional humour shows on Colombian television was heavily criticized for the presence of a character called Soldado Micolta, who for many ridiculed Afro-Colombians. The show removed this character, but not without a great discussion about what was perceived by some as a limitation to freedom of speech and an injustice towards the actor.

I could indicate many other situations, with more or less resonance in the media and on social networks, beyond those mentioned above. Nevertheless, that summary is sufficient to illustrate my point that in Colombia, a series of discourses and disputes regarding racism - which were hardly visible just three decades ago - have been positioned today in the public sphere. This does not mean that situations like these have not happened before, since racial discrimination in the country is by no means a novel issue.

I believe, however, that it is worth considering that the increasing visibility of these situations in the media and social networks also has to do with the transformations in the principles of intelligibility and the thresholds of tolerance that have made it possible to state and experience life in different terms that previously did not necessarily appear in a racialization key. My argument, of course, is not that before there was a kind of false consciousness that today has been happily dissipated allowing to see and feel the world 'as it is'. Neither do I pretend to argue that what was previously uncommon in the registry of social media and networks' portrayal of racialization cannot be explained as an expression of racial discrimination practices, regardless of if it is experienced as such or not.

My point here is that this increasing visibility of racism talks and disputes in the media and social networks indicates that substantial transformations are taking place in how racism is shaped, enunciated and experienced today in Colombia among the sectors of the population addressed by these registers.

The principles of intelligibility and thresholds of tolerance that allow the possibility of these talks and disputes have been transformed in the last decades in the country due to multiple factors that I can only mention quickly since elaborating about each one of them would require an entire new article. One of the factors that contributes to explain these transformations is that social networks have facilitated everyday contact with transnational horizons of meaning, along with virtualized media where the forums and opinions of many people can be registered.

Another factor to take into consideration are the agendas and effects of the interventions by international cooperation agencies that develop programmes to raise awareness about racism, together with the predominantly racialized terms they use and from which their economic resources derive. In these programmes, both the social domain and inequality issues are made sense of, and divided in terms of 'afros', 'indigenous' and 'mestizos' (or 'whites'). 
The emergence and consolidation of organizations focused on the struggles against racism and racial discrimination of Afro-descendants with strong media strategies - such as 'Chao Racismo' - also play a prominent role in these transformations. Fuelling this phenomenon, there is the transnationalization of activists and organizations of black communities, as in the case of the Black Communities Process, who have found in the discourses and scenarios articulated since the World Conference against Racism in Durban, a translation of their demands for the recognition of ethnic-territorial rights, initially conceived in a horizon of cultural difference and now in the key of anti-racism struggle.

\section{Talks and disputes of racism in activism and the academic establishment}

Afro-Colombian activist Aiden Salgado published an article on the well-known webpage Las 2 Orillas titled 'Is the Police the only racist institution in Colombia?'2 According to Salgado, the case of Carlos Angulo should not be considered an isolated event, but a situation faced daily by many AfroColombians in different cities of the country. Racial discrimination and racism are not limited to the police; rather, they go much further:

The problem is structural, it is society and unfortunately it is replicated everyday by institutions from the media to the educational system. We live in a racist and classist society. Facing this reality is not enough to be outraged by events like what happened to Carlos Angulo Góngora, but we need to recognize that we live in a racist society that brings with it disadvantages to a good number of the population who are Afro-Colombians.

According to Salgado, racism as an structural problem is expressed in the following: (1) '[...] at the highest levels of the Colombian State there are no Afro-Colombian or black people'; (2) '[...] the places where AfroColombian or black people live are the most abandoned by the State'; (3) '[...] the index of unmet basic needs shows that this is a reality largely experienced by Afros'; (4) '[...] in our region of the Pacific and in the cities of Quibdó and Buenaventura basic services are not guaranteed'; (5) 'There is a major lack of Afro people in the universities, both as reflected in academic contents and as individuals'; and (6) television '[...] ridicules and creates negative and despicable stereotypes of the Afro-Colombian population'.

Salgado's denunciation of racism cannot be considered a novelty since such pronouncements and writings against racism can be found as far as the second half of the twentieth century. For example, in an article in the local press about the Third National Congress of Negritude, held in Quibdó from 23 to 25 September 1976, there are passages on the ideological platform of negritude, such as the following: 
It is evident that racism in Colombia is not a mirage. Unemployment is proportionally higher among Blacks than white folk. The same thing happens with infant mortality, illiteracy, tuberculosis, etc. The role of Blacks is determined by capitalist society. The Black person is doubly exploited: because of his economic situation and because of his racial condition [...] racial minorities suffer cultural hypertrophy by mass media, TV, the press, radio, cinema, etc. all of which are in the hands of powerful monopolies controlled by the white ruling class. These are the means of channeling racism and oppression. (Saturio 6: 8 Sep 1976)

Notwithstanding the evident similarities between the quoted passages of Salgado's denunciations and those of the ideological platform of negritude, some differences in language can be drawn which are not at all minor. By the 1970s, notions such as capitalism, oppression, exploitation, class and black circulated more frequently due to the historical moment and the prevailing theoretical and political paradigms. Today, notions such as Afro-descendants, Afro, Afro-Colombians, black people, black communities, ethnicity, ethnic group, cultural identity and territory are often evoked when racism and racial discrimination are discussed.

These transformations in language express a subtle shift in the principles of intelligibility and readability of racism and racial discrimination. This displacement is informed in part by the shift to multiculturalism, by its horizons of incorporation and recognition. Neo-liberal policies and imaginaries have been in place during these transformations, although there is no causal relation among them, nor are they opposed to each other, but they have coexisted. But also, these transformations incorporate other factors such as the relatively recent relevance of the race category and the growing concern about racism in the country's academic establishment.

In relation with these transformations in the academic talks and disputes about race and racism, the publication of the translation to Spanish of Peter Wade's book Black People, a Mixed Nation, has a preface in which he explains in detail his use of the concept of race, as well as the theoretical reasons for its relevance (Wade 1997). This clarification responded, among other things, to the misunderstanding derived from what I would like to call the 'itching' towards the term race among Colombian readers of that time. This itch has not disappeared as has been clear in some of the disputes framed as race and racism above indicated, although has been substantially attenuated. By the 1980s, race was a kind of forbidden word among many anthropologists and other social scientists in Colombia.

The central argument for discarding race from the analytical toolbox was that the word race was necessarily associated with the promotion of racism. The use of this word had to be conjured, which, as science had well demonstrated, had no existence as a biological fact. The argument was that retaining its use in the analysis had no other effect than to reify its existence and, thus, to underpin racism. In its replacement, most Colombian anthropologists and 
social scientists resorted to notions such as ethnicity, ethnic group or culture. The problems of inequality, marginality and discrimination of black people were addressed, but mostly in a culturalist vocabulary or in class perspective that avoided the explicit allusion to race and racism.

Although in disciplines such as sociology or history such an attitude towards the term of race was not so generalized, a greater preoccupation in the majority of scholars with the study of the processes of racialization and racial discrimination can be largely attributed to this sting. Thus, for Catalina Cavelier,

[...] racial studies have developed late, most of them in the present decade. I consider that much of what explains this late development to which I refer can be found in the culturalist and ethnicist approach from which the anthropological studies of black people have been observed. $(2007$, p. 5)

This is not the place to go into the reasons why the analyses of Colombian academics in the 1980s and early 1990s were not usually articulated in terms of race and racism. For the purposes of this article, I am interested in drawing attention to the fact that today the clarifying preface to the translation of Peter Wade's book would not be necessary. Race, racism, racialization and racial discrimination have become usual analytical categories and research problems in Colombia, even in the anthropological field.

This positioning of race and racism as an analytical category and a major concern for the study of racialization, racial discrimination and racism processes should not be naively understood. This does not mean that the country's academy has managed to tear apart the veil of ignorance and overcome the underlying racism that prevented it from understanding the world as it really is. Neither does it mean that today we are actually addressing issues and problems in the right way, with categories that are 'naturally' the most relevant, in contrast to a prior time of misconceptions and malevolent ignorance. This teleological and self-indulgent conception has a dehistorizing effect that clouds understanding of the limitations and anchorages from which we elaborate our theories, but about which we rarely think of.

As Rita Laura Segato (2007) points out, we cannot ignore the fact that analytical categories and theoretical paradigms are part of transnational networks in which localized common academic tendencies tend to be universalized and hegemonized through subtle authorization and recognition devices. The fact that the agendas of academics in Colombia today turn more frequently to think from categories such as race and that in their maps of problematic relevance, racism and racial discrimination are more relevant, it is not something that should escape the analysis. On the contrary, the genealogy of how this has been achieved and the ethnography of its performative effects constitute an important streak of analysis that we cannot disregard on behalf of political urgencies. 


\section{Conclusion}

In the shift to multiculturalism in Colombia, two major phases can be traced in relation to Afro-descendants. The first one, which includes the 1990s and the first years of the present century, presented the political and legal subject of black communities as an ethnic group and referred fundamentally to the region of the Colombian Pacific. Within this period, the visibility of the organizational movement, along with achievements such as the collective titling of more than five million hectares, evidenced an important political positioning of the struggles in terms of ethnic-territorial rights. The second one, which is more recently consolidated, is characterized by the growing legal and political interpellation of black population sectors in urban contexts and in rural areas outside the Pacific region, based on an extension of the subject of rights and mobilization beyond the ethnic-territorial approach to include Afro diasporic and anti-racist agendas, while in real life the rights achieved on paper are undermined by the state and from both legal and illegal business interests.

This shift to multiculturalism has not meant the disappearance of the talks and disputes of racism and the beginning of a kind of 'post-racial' social formation, as some would have expected with the recognition of the rights of black communities as an ethnic group. On the contrary, parallel to this turn, a growing visibility of the speeches and disputes of racism is traceable, some of these uttered precisely by the accusations that the texts of the legislation referring to black communities promote racism. This seems in part a reaction of those who propose the ethnic concept against the race concept. Similarly, in the media and social networks, there is also an increase in the number of situations that triggered racism talks and disputes since the 1990s when the shift to multiculturalism took place.

For activists, including those who led the mobilizations and organizations that drove the shift to multiculturalism, the black community's ethnic rights struggles have increasingly merged with talks and disputes of racism. What for some may have been considered as a struggle primary defined in terms of the recognition of cultural difference in black communities with traditional practices of production, collective territories and a particular cultural identity has been explicitly intertwined with racism's talks and disputes, to the point of now interpreting the limitations in the recognition of these rights (such as the prior consultation) as an evident manifestation of racism. One might analytically and politically differentiate various sorts of arguments among these talks and experiences of race and racism, which is something that goes beyond this paper. However, my point is to highlight the fact of the discursive eruption of race and racism in a particular moment in Colombia associated with the positioning of multiculturalism, which for a naïve narrative could mean the beginning of a 'post-racial' social formation. 
In the academic establishment, on the other hand, appeals referring to race as an analytical category and concerns about racism and anti-racist struggles ceased to be matters addressed in different terms, to find ourselves today in a situation where the conceptual frameworks that articulate the category of race and the problems of the inequality and discrimination are taken for granted, and often strongly read in key of racism.

In sum, it can be affirmed that the principle of intelligibility and the thresholds of tolerance that divide the world between 'afros' (or 'black communities'), 'indigenous' and 'mestizos' (or 'Whites') have been so positioned in recent years in Colombia that the shift to multiculturalism can be understood as a preamble to what seems to position itself as an increasingly racialized theoretical and political imagination.

\section{Notes}

1. For example, in a television show dedicated to race and racism from Canal Capital, people on the street were asked by journalists if there was racism in the country or not. The show can be watched in the following link: https:// www.youtube.com/watch? $\mathrm{v}=\mathrm{LDHXI} 8 \mathrm{wdu} 0$.

2. See http://www.las2orillas.co/sera-solo-la-policia-una-institucion-racista-en-colo mbia-3/.

\section{Acknowledgements}

The author appreciates the comments and debates with the members of the Colombian team: Rosbelinda Cárdenas, Eliana Antonio Rosero and Charo Mina-Rojas.

\section{Disclosure statement}

No potential conflict of interest was reported by the author.

\section{Notes on contributor}

Eduardo Restrepo is a social anthropologist who has done intensive research on the concept and history of blackness in Colombia, and has examined constructions of otherness, multiculturalism and postcolonial theory. His books include Etnizacion de la negridad. Invencion de las comunidades negras como grupo étnico en Colombia. He is currently Professor in the Department of Cultural Studies, Pontificia Universidad Javeriana, Bogotá.

\section{References}

Arias, J., 2005. Nación y diferencia en el siglo XIX colombiano. Orden nacional, racialismo y taxonomías poblacionales. Bogotá: Ceso-Uniandes.

Caldeira, T., 2001. City of walls: crime, segregation, and citizenship in São Paulo. Berkeley, CA: University of California Press. 
Cavelier, C., 2007. El racismo desde la academia: contexto y aproximaciones a la problemática del racismo y la discriminación racial en el ámbito de las ciencias sociales en Colombia. Documento de trabajo. Observatorio de Discriminación Racial. Universidad de los Andes.

Dagnino, E., 1998. The cultural politics and democracy: changing discourse and practices of the Latin American left. In: S. Alvarez, E. Dagnino, and A. Escobar, eds. Cultures of politics/politics of cultures: re-visioning Latin American social movements. Boulder, CO: Westview Press, 33-63.

Escobar, A., 2008. Territories of difference: place, movements, life, redes. Durham, NC: Duke University Press.

Hale, C., 2006. Más que un indio (more than an Indian): racial ambivalence and neoliberal multiculturalism in Guatemala. Santa Fe, NM: School of American Research Press.

Hall, S., 1985. Signification, representation, ideology: Althusser and the post-structuralist debates. Critical studies in mass communication, 2(2), 91-114.

Hall, S., 1988. The hard road to renewal. Thatcherisim and the crisis of the left. London: Verso.

Hoffmann, O., 2007. Comunidades negras en el Pacífico colombiano. Innovaciones y dinámicas étnicas. Quito: Instituto Francés de Estudios Andinos.

Lemaitre, J., 2009. El derecho como conjuro: Fetichismo legal, violencia y movimientos sociales. Bogotá: Siglo del Hombre Editores.

Lopera, G. and Dover, R., 2013. Consulta Previa, ciudadanías diferenciadas y conflicto socioambiental. Boletín de Antropología, 28 (45), 76-103.

Mosquera, J.E., 1995. La cara oculta de la Ley de Negritudes. El Espectador. Pacífico Siglo $X X I$, Vol. 39, 24 April.

Segato, R., 2007. La nación y sus otros. Raza, etnicidad y diversidad religiosa en tiempos de políticas de la identidad. Buenos Aires: Prometeo.

Restrepo, E., 2013. Etnización de la negridad: la invención de las comunidades negras como grupo étnico. Popayan: Editorial de la Universidad del Cauca.

Rosas, M., 2013. El rol performativo de la jurisprudencia constitucional respecto a la comunidad negra como entidad juridica. Dialgo de Saberes, 39, 89-104.

Ruíz, D., 2008. Nuevas formas de ser negro: consideraciones sobre las identidades entre la gente negra y chilapa del bajo Atrato chocoano. In: I. Bolívar, ed. Identidades culturales y formación del estado en Colombia. Colonización, naturaleza y cultura. Bogotá: Universidad de los Andes, 209-248.

Urrea, F. et al., 2014. From whitened miscegenation to tri-ethnic multiculturalism: race and ethnicity in Colombia. En: E. Telles, ed. Picmentocracies: ehtnicity, race, and color in Latin America. Chapel Hill, NC: University of North Carolina Press, 79-125.

Valencia, H., 1998. Antropologia de la familia chocoana. Medellín: Editorial Lealón.

Wade, P., 1993. Blackness and race mixture: the dynamics of racial identity in Colombia. Baltimore, MD: Johns Hopkins University Press.

Wade, P., 1997. Gente negra, nación mestiza. Dinámicas de las identidades raciales en Colombia. Bogotá: Ediciones Uniandes. 